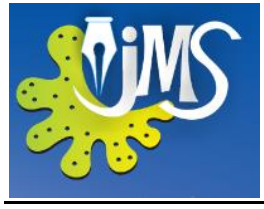

\title{
Determinants of Customer Satisfaction in Freight Forwarding Companies in Sri Lanka
}

\author{
Dias A.A.C.N., Jayarathna D. G. N. D *,and Madhushani P.W.G. \\ Faculty of Management, Humanities and Social Sciences, \\ Colombo International Nautical \& Engineering College (CINEC), Colombo, Sri Lanka
}

\begin{abstract}
Despite bringing enormous profit to the company as well as the development of the country, freight forwarding is still considered as a developing field in Sri Lanka. Freight forwarders usually work with agents, forwarders, small or medium size manufacturers, therefore, having a close customer relationship is a vital role which could sustain the freight forwarding industry competitive.

This study investigates the determinants of customer satisfaction in freight forwarding companies in Sri Lanka. Primary data was collected by means of an online questionnaire from freight forwarders in the Western province of Sri Lanka and overall 258 valid questionnaires were used for the analysis. Besides, an auxiliary analysis was carried out using 19 potential influential factors which derived eight factors to determine the overall customer satisfaction which titled as reliability, responsiveness, communication and documentation accuracy, assurance, empathy, branding, technology, efficiency and trust. Hence in a situation where the growth rate for the logistics industry is drastically increasing, this thesis is important for further improvement of customer relationship in freight forwarding companies in Sri Lanka.
\end{abstract}

KEYWORDS: Freight forwarding, Customer satisfaction, Logistics.

Corresponding author: Jayarathna, D. G. N. D., Email: nuwan@cinec.edu 


\section{INTRODUCTION}

Since 1980s open economic environment results in a massive growth in imports and exports sector in Sri Lanka which requires efficient freight forwarding solutions in order to cater the trading demand thus freight forwarding companies and logistics industry had to make a revolution in the industry. However, there was an issue as the industry was unregulated and had no controlling body to ensure freight forwarders work process where different forwarders in different countries play as per their own terms.

Nevertheless, uniformity among freight forwarders is utmost important thus Sri Lanka Freight Forwarders Association (SLFFA) was officially opened for standardized the industry which is a milestone in freight forwarding industry in Sri Lanka. All of these standard and efficient processes are required for offering a better service to customers as customers are the most important aspect in the service industry. Thus, from the perspective of customers, service required is different from one country to another and in the Sri Lanka context as well. Indeed, making loyal customers satisfy in order to retain customers and showing a competitive advantage for attracting new customers is very important. But in contrast, it is been competitive in Sri Lanka due to the requirement of customized services whilst having well-executed systems.

Accordingly, with the global competition more than ever before, freight forwarding companies are now ready to use relationship marketing strategy to build, maintain and enhance the solid relationship with customers to secure customer loyalty with the aim of making customer satisfaction for better loyalty.

Therefore, the objectives of this research are;

จ To determine the factors affecting customer satisfaction in freight forwarding companies in Sri Lanka.

- To study customer satisfaction among freight forwarding companies in Sri Lanka.

- To propose solutions to enhance customer satisfaction in freight forwarding services in Sri Lanka.

\section{LITERATURE SURVEY}

\subsection{Role of Freight Forwarder}

Freight forwarding is a "services of any kind relating to the carriage, consolidation, storage, handling, packing or distribution of the Goods as well as ancillary and advisory services in connection therewith, including but not limited to customs and fiscal matters, declaring the Goods for official purposes, procuring insurance of the Goods and collecting or procuring payment or documents relating to the Goods" (Malika, 2015)

\subsection{Freight Forwarders as Decision- Makers in Multimodal Transport}

Freight forwarders are being one of the decision makers employed in choosing the appropriate transportation mode. A freight forwarder organizes the safe, efficient movement of goods on behalf of an exporter, importer or another company operation, sometimes including dealing with packing and storage. (Gourdin, 2006) as cited in (Horch, 2009) defined the main 
task of freight forwarders as combining many small shipments into a single large one by providing fewer freight rates. The traditional forwarding function can be divided into documentation planning and costing routes, booking and coordinating freight, arranging ancillary services such as warehousing and packing, consolidation, paying charges due to carriers, ports, customs etc. However, the role of the freight forwarder is to complete the work done with customer satisfaction as per the decision made by the customer in order to maintain customer loyalty for future business as well.

\subsection{Customer Service in Logistics}

The three main elements of customer service in logistics are pre-transaction, transaction and post-transaction. The first one means that the factors of customer service occur before the actual order takes place. These elements must be provided by the supplier, for instance, supplier should make sure whether the stock is still available and order cycle time is appropriate and consistent. Secondly, transaction elements are directly linked to the transaction and most commonly concerned with logistics. Customers usually evaluate customer service quality based on these factors such as accurate invoices and orders, on-time delivery, consistent product quality, etc. Last but not least, post-transaction elements relate to the factors occurring after the delivery takes place. This element has two sub-categories: relationship service and relationship quality. The former one includes after-sales support, actual delivery time, helpful customer service representatives and offered customized services. The latter one relates to trust, commitment and integrity between supplier and client (Truong, 2012).

\section{METHODOLOGY}

The survey was conducted by using an online distributed questionnaire which was available for 45 days in the internet focusing on western provincial freight forwarders due to the inability of covering all the SLFFA registered Freight Forwarders Island wide. According to the research topic, the researcher has identified variables which are affecting the research output as independent and dependent variables through the Literature reviews carried out in the research.

Primary data has been collected through the above said online questionnaire and secondary data was collected through reports, books, journals, and articles as well. A convenient sample of 108 freight forwarders was selected for data collecting using simple random sampling method whilst 4 questionnaires have been distributed for each company focusing on 300 responds to the survey.

As a result, 258 responses have been received which is more than $50 \%$ response rate. In the meantime, descriptive analysis has been conducted for demographics data presentation and SPSS analytical software was used for analyzing the factors. The method used was Bartlett's \& Kaiser-Meyer-Olkin (KMO) test, Communalities, Total Variance, and Rotated Component Matrix, Chi-square and etc.

\section{RESULTS \& DISCUSSION}

\subsection{Descriptive Analysis}

According to the respondents which were satisfied with the rate is given was $81.3 \%$ where not satisfied response was $18.6 \%$ where it concludes that more companies in Sri Lanka already agrees with the current freight 
rates using in the freight forwarding industry in Sri Lanka.

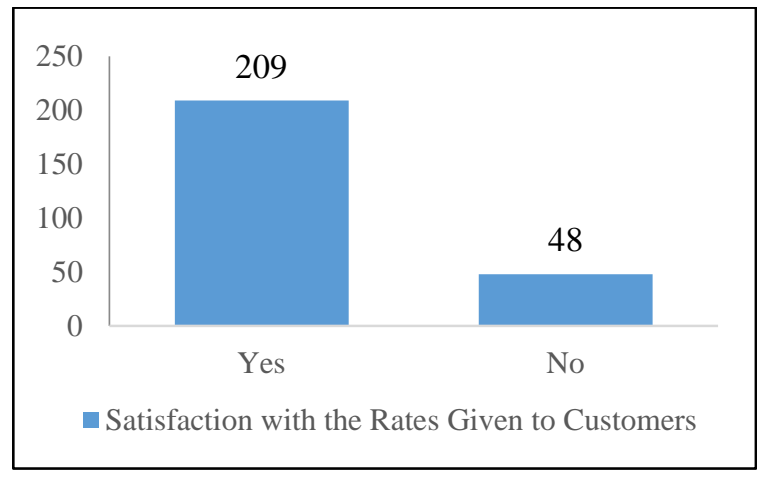

Figure 1: Satisfaction with the Rates Given to Customers

As shown in Figure 2, majorities of the respondents in the sample represents as they have below 3 years partnership with freight forwarding companies which accounts for $48 \%$ of the sample and $19 \%$ of companies have experience with 3-5 years. Especially $33 \%$ of FF companies have over 5 years of partnership experience where it can conclude that there is more reliable FF companies also existed in the industry whilst lots of FF companies turnover in the market place.

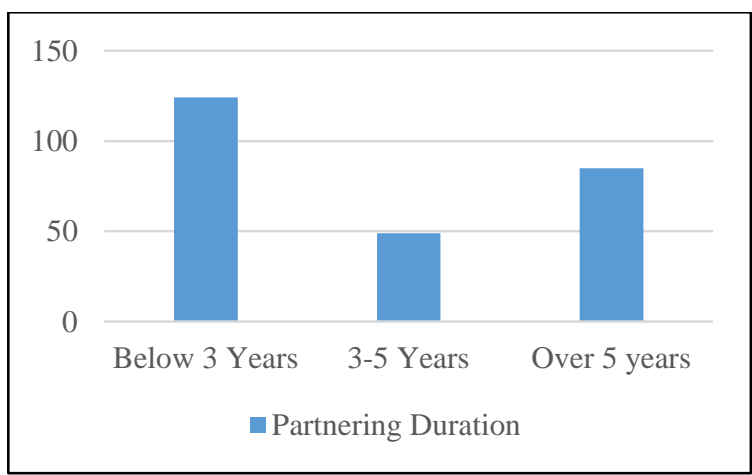

Figure 2: Partnering Duration

\subsection{Cross Tabulation Hypothesis testing}

Table 1: Hypothesis Testing Statistics

\begin{tabular}{|l|l|}
\hline \multicolumn{1}{|c|}{ Pair of Variables } & P Value \\
\hline $\begin{array}{l}\text { Listen to customers' feedback Vs } \\
\text { take care and pay attention to } \\
\text { customers }\end{array}$ & .000 \\
\hline $\begin{array}{l}\text { Gain total trust from customers Vs } \\
\text { Keeping and Following their } \\
\text { promise }\end{array}$ & .000 \\
\hline $\begin{array}{l}\text { Always try to avoid mistakes and } \\
\text { accidents Vs Customers feel safe } \\
\text { when doing transactions }\end{array}$ & .000 \\
\hline $\begin{array}{l}\text { Free resolve if there are errors in } \\
\text { documentation Vs Resolve all } \\
\text { complaint satisfactorily }\end{array}$ & .001 \\
\hline
\end{tabular}

For the above information following hypothesis can be built.

$\mathrm{H}_{0} \mathrm{~A}$ : Listen to customers' feedback is independent from taking care and pay attention to customers.

$\mathrm{H}_{1} \mathrm{~A}$ : Listen to customers' feedback is dependent from taking care and pay attention to customers.

$\mathrm{H}_{0} \mathrm{~B}$ : Gaining total trust from customers is independent from Keeping and Following their promise

$\mathrm{H}_{1} \mathrm{~B}$ : Gaining total trust from customers is dependent from Keeping and Following their promise

$\mathrm{H}_{0} \mathrm{C}$ : Trying to avoid mistakes and accidents is independent from feeling safe when doing transactions 
$\mathrm{H}_{1} \mathrm{C}$ : Trying to avoid mistakes and accidents is dependent from feeling safe when doing transactions

$\mathrm{H}_{0} \mathrm{D}$ : Free resolve if there are errors in documentation is independent from resolving all complaint satisfactorily

$\mathrm{H}_{1} \mathrm{D}$ : Free resolve, if there are errors in documentation, is dependent from resolving all complaint satisfactorily

As per the p-value of all the pair of variables are less than 0.05 hence it can be concluded that the null hypothesis of all the above hypothesis can be rejected and thereby can come to a conclusion that all the first variable in the above pair of variables are dependent on the second variable of the above pair of variables

\subsection{Factor Analysis}

Table 2: Reliability Analysis

\begin{tabular}{|l|l|l|}
\hline $\begin{array}{l}\text { Cronbach's } \\
\text { Alpha }\end{array}$ & $\begin{array}{l}\text { Cronbach's Alpha } \\
\text { Based on } \\
\text { Standardized Items }\end{array}$ & $\begin{array}{l}\mathrm{N} \text { of } \\
\text { Items }\end{array}$ \\
\hline .749 & .774 & 19 \\
\hline
\end{tabular}

According to the results of table 2, the value of Cronbach's Alpha is 0.749 which illustrates better Cronbach's Alpha value. Thus, the reliability of the variables is in a better level and data set can be accepted.

Table 3: KMO and Bartlett's Testing

\begin{tabular}{|l|l|c|}
\hline \multicolumn{2}{|l|}{$\begin{array}{l}\text { Kaiser-Meyer-Olkin Measure of } \\
\text { Sampling Adequacy. }\end{array}$} & .689 \\
\hline $\begin{array}{l}\text { Bartlett's } \\
\begin{array}{l}\text { Test of } \\
\text { Sphericity }\end{array}\end{array}$ & Approx. Chi-Square & $2.586 \mathrm{E} 3$ \\
\cline { 2 - 3 } & Sig. & 171 \\
\cline { 2 - 3 } & Sig. & .000 \\
\hline
\end{tabular}

The strength of the relationship among variables is measured using Kaiser-MeyerOlkin (KMO) and Bartlett's test. KMO test statistic measures the sample adequacy. Since KMO test statistic is greater than 0.6 , it can be concluded that the sample is adequate and suitable for factor analysis. According to the table 3 value of Kaiser-Meyer-Olkin is 0.689 where it can be concluded that the sample is adequate.

The hypothesis is given below,

$\mathrm{H}_{0}$ : Correlation matrix is an identity matrix.

$\mathrm{H}_{1}$ : Correlation matrix is not an identity matrix.

Furthermore, significant value is 0.000 where it is lower than the recommended $P$ value of 0.05 which lead to rejecting the Null hypothesis hence Correlation matrix is not an identity matrix.

Table 4: Total Variance Explained

\begin{tabular}{|c|c|c|c|c|c|c|}
\hline \multirow{2}{*}{ 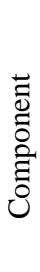 } & \multicolumn{3}{|c|}{ Initial Eigenvalues } & \multicolumn{3}{|c|}{$\begin{array}{l}\text { Extraction Sums of } \\
\text { Squared Loadings }\end{array}$} \\
\hline & 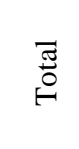 & 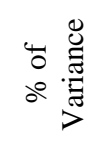 & 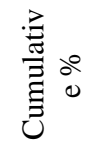 & 丞 & 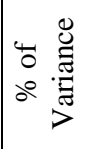 & 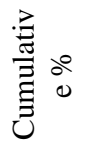 \\
\hline 1 & 4.812 & 25.325 & 25.325 & 4.812 & 25.325 & 25.325 \\
\hline 2 & 2.184 & 11.496 & 36.821 & 2.184 & 11.496 & 36.821 \\
\hline 3 & 1.499 & 7.889 & 44.710 & 1.499 & 7.889 & 44.710 \\
\hline 4 & 1.296 & 6.819 & 51.530 & 1.296 & 6.819 & 51.530 \\
\hline 5 & 1.240 & 6.526 & 58.056 & 1.240 & 6.526 & 58.056 \\
\hline 6 & 1.186 & 6.241 & 64.297 & 1.186 & 6.241 & 64.297 \\
\hline 7 & 1.160 & 6.105 & 70.402 & 1.160 & 6.105 & 70.402 \\
\hline 8 & .966 & 5.085 & 75.488 & .966 & 5.085 & 75.488 \\
\hline 9 & 839 & 4.415 & 79.902 & & & \\
\hline
\end{tabular}


As per to table 4, factors are summarised through the Eigenvalues which are greater or closer to one, therefore it initially concludes main 7 factors which have Eigenvalue of greater than one which represents the overall 19 factors in the study however there is another Eigenvalue which more closer to one which is .966 and has the capability to be included in the model hence the above table is generated based on those 8 factors which have overall $75.488 \%$ of variance explained by this model.

Those 8 factors are; Empathy, Reliability, Communication and Documentation Accuracy, Responsiveness, Assurance, Efficiency and Trust, Branding and Technology.

Cronbach values of generated factors greater than 0.6 and are considered to be reliable. Thus, Cronbach value of factors $1,2,3,4,5$ and 6 are $0.805,0.997,0.731,0.785,0.607$ and 0.706 respectively.

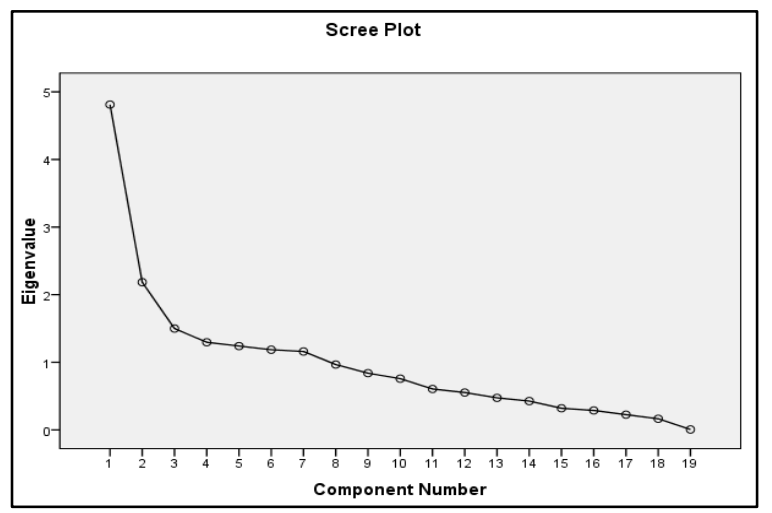

Figure 3: Scree Plot

According to figure 3, there is a sharp turn (elbow) after the 8th Eigenvalue. Therefore, it can be concluded that 8 factors are sufficient to account the total variation. It is further confirmed by the Extraction Sums of Squared
Loadings. For further analysis, only eight factors have retained.

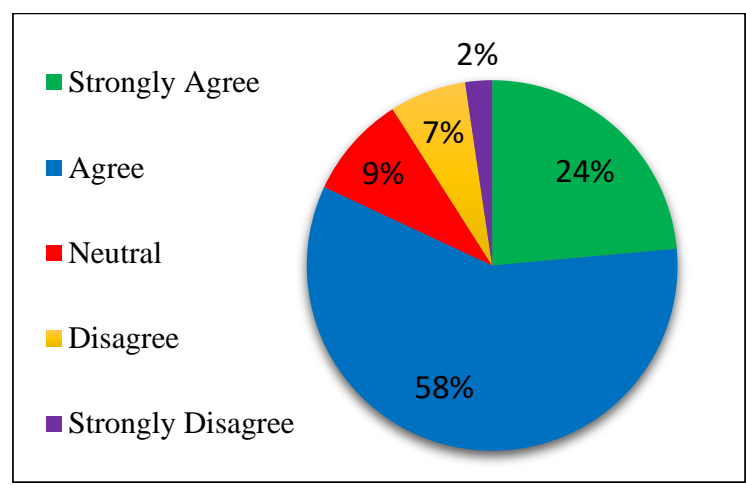

Figure 4-Overall Customer Satisfaction

Regarding the overall customer satisfaction in the service quality of Colombo based freight forwarding services were strongly agreed on $22.2 \%$ and agreed 55\% while on $8.5 \%$ neutral, disagree $6.3 \%$ and finally strongly disagree on $2.2 \%$ which can be concluded that the present situation in the freight forwarding industry is on its satisfactory level in Sri Lanka.

\section{CONCLUSION}

Findings of the analysis are summarised here with the intention of matching objective with the findings. In the demographic analysis, out of 300 questionnaires which were distributed among freight forwarding companies, 258 valid responses were collected whereas most of the responses account into the category of interns and contractual where the analysis is mostly based on responses of middle-level positions in the freight forwarding industry.

However, the $81.3 \%$ of the respondents which are satisfied with the rates given in the industry are mostly from the perspective of interns and contractual where it concludes that industry is in its satisfactorily level in Sri Lanka when comparing with the rates given. 
Rather, partnering with companies is not only a factor of given rates but also there are more factors such as trust, reliability, and experience. Etc. Hence most of the companies have higher turnover rates due to low experience and failure to maintain trust and reliability whilst the respondents that have a relationship over five years also exist in the industry due to the building of trust with the customer.

In the factor analysis, it wraps up that all the 19 factors can be compressed into final 8 factors which represent the industry variance with $75.48 \%$. Those summarised factors are Empathy, Reliability, Communication and Documentation Accuracy, Responsiveness, Assurance, Efficiency and Trust, Branding and Technology where above factors help to identify the scenarios where the freight forwarding industry should be prioritized, improved where factors which were not significant should not be highlighted.

Finally, service quality is determined by the customers and is ultimately measured in the total satisfaction level hence in order to ensure high service quality; the company must strive to meet customers' needs and expectations in the service offer and throughout every stage of the service delivery.

In recommendation for the government, planning and upgrading infrastructure are the most important priorities. Logistics operations cannot develop if infrastructure, ports, warehouses, etc. are not invested properly. Therefore, the government should improve infrastructure to meet the rising needs of logistics, reduce logistics cost and increase competitiveness for Sri Lankan freight forwarders because narrow road system and traffic jams everywhere are one of the emerging problems at the moment.

In addition, Sri Lanka Customs should be further improved and should be modernized as soon as possible. Not only Sri Lanka customs procedures are very complicated and not transparent but customs staffs are also authoritarian and corrupted, which really affects the quality of logistics services as well as the development of the domestic freight forwarding industry.

\section{ACKNOWLEDGMENT}

Authors wish to acknowledge academic and non-academic staff members in CINEC Campus for providing guidance to make this research a success. Also, special thank goes to Freight Systems Lanka for providing research information as well. Finally, my colleagues and all other people who have given their support in this regard are highly appreciated as well.

\section{REFERENCES}

ALICAN, A. (2012) Evaluating Customer Loyalty In Association with CRM in Freight Forwarder Firms. Department of Marketing and Logistics, Jonkoping International Business School. Vol 40, Pp. 1004 -101

DANIEL, C. N., LUKONG, L. P. (2010). Using the SERVQUAL model to assess service quality and customer satisfaction. An Empirical Study of Grocery Stores in Umea.

JULIA, O. ULRIKA, W. (2014) Analysis Of Customer Needs and Service Quality at a Liner Shipping Company, Department of 
Technology Management and Economics Chalmers University of Technology.

KEE, K. CHING, T. CHENG, S. (2008) Service Quality Gaps of Business Customers in the Shipping Industry, National Taiwan Ocean University.

MALIKA, W. (2015) Review of Logistics Service Regulations for Freight Forwarding Businesses. Trade and Competitiveness Global Practice Group.

OTHELIUS, J., WEMMERT, U. (2014). Analysis of Customer Needs and Service Quality at a Liner Shipping Company.

SLFFA, (2015) About Sri Lanka Logistics and Freight Forwarders Association.

SLFFA, (2016) History of Sri Lanka Logistics and Freight Forwarders Association.

SHENG, T. (2013) Customer Satisfaction Evaluation of Liner Shipping and Logistics Service by Using Quality Function Deployment. University of Kobe.

SUNG, H, JIN, W. (2014), A Study on Importance and Satisfaction of Forwarders as to Airline Services: Based on the Main Export Route Of Korean Market.

TANYAPORN, K. (2014) A Study of Factors Influencing Customer Satisfaction: An Implementation on Thai Postal Service, Bangkok Area, International Conference on Business, Law and Corporate Social Responsibility.

TRUONG, L. (2016) Improving Logistics Service Quality in Freight-Forwarding in Hochiminh City, Vietnam. Helsinki Metropolia University of Applied Sciences.
VAVRA, T.G. (1997) Improving Your Measure of Customer Satisfaction: A Guide to Creating, Conducting, Analyzing, and Reporting Customer Satisfaction Measurement Programs. American Society for Quality, Milwaukee, WI. 